кандидат юридических наук, доцент кафедры международного права Северо-Кавказского филиала Российского государственного университета правосудия

Бородаенко Анна Андреевна

кандидат юридических наук, старший преподаватель кафедры международного права

Северо-Кавказского филиала Российского государственного университета правосудия, член Российской Ассоциации международного права

\section{РАСШИРИТЕЛЬНОЕ ТОЛКОВАНИЕ МЕЖДУНАРОДНОГО ПРАВА В ЦЕЛЯХ ОБЕСПЕЧЕНИЯ МИРА И БЕЗОПАСНОСТИ (НА ПРИМЕРЕ УЧРЕЖДЕНИЯ МЕЖДУНАРОДНЫХ УГОЛОВНЫХ ТРИБУНАЛОВ)}

Аннотация:

В статье приведен анализ действий основных субъектов международного права по исполнению требований международного права в тех или иных ситуациях. В частности, рассмотрены действия государств по учреждению Нюрнбергского и Токийского военных трибуналов, изучены резолюции Совета Безопасности ООН по учреждению Международного трибунала по бывшей Югославии (МТБЮ) и Международного трибунала по Руанде (MTP). По результатам исследования дана оценка политики государств, направленной на «обход» требований международного права во имя сохранения международного мира и безопасности, способствование наискорейшему исчерпанию конфликтной ситуации.

Ключевые слова:

международный мир, безопасность, Устав, Совет Безопасности, ООН, компромисс, трибунал, расширительное толкование.
PhD in Law, Assistant Professor, International Law Department, North Caucasus branch of Russian State University of Justice

Borodaenko Anna Andreyevna

PhD in Law, Senior Lecturer, International Law Department, North Caucasus branch of Russian State University of Justice, Member of the Russian Branch of the International Law Association

AN EXPANSIVE INTERPRETATION OF INTERNATIONAL LAW TERMS IN ORDER TO ENSURE PEACE AND SECURITY (BY CASE STUDY OF INTERNATIONAL CRIMINAL TRIBUNALS)

The article provides an analysis of the main subjects of international law for the enforcement of the international law requirements in certain situations. In particular, the paper reviews the countries' tactics during the establishment of Nuremberg and Tokyo Military Tribunals. It examines the UN Security Council Resolutions on the establishment of the International Criminal Tribunal for the Former Yugoslavia (ICTY) and the International Criminal Tribunal for Rwanda (ICTR). As a result, the authors estimate the state policy that is intended to circumvent the international law requirements in the name of international peace and security contributing to the fastest conflict resolution.

Keywords: international peace, security, Charter, Security Council, UN, compromise, tribunal, expansive interpretation.

Сообщество равных участников, ни один из которых не имеет явного преимущества перед другими, всегда стремится к балансу порой противоречивых и взаимоисключающих интересов. Основные субъекты международного права, пытаясь достичь компромисса и создать качественно новый продукт правовой мысли, часто вынуждены применять революционные методы, не сочетающиеся с актуальными представлениями о сути международных отношений. Последующее развитие нормативной и доктринальной составляющих международного права, как правило, указывает на то, что большинство подобных нововведений воспринимаются позитивно. Так, согласно позиции Р.А. Каламкаряна и Ю.И. Мигачева, деятельность Нюрнбергского и Токийского военных трибуналов, трибуналов по бывшей Югославии и Руанде оказала значимое положительное влияние на формирование современного международного права [1, с. 115].

Считаем необходимым подробно проанализировать некоторые имевшие место факты обхода актуальных требований международного права в пользу развития новых прогрессивных положений, выработки революционных идей и концепций мирного сосуществования, сохранения атмосферы безопасности в отдельно взятом регионе или государстве. Представляется хронологически обоснованным начать рассмотрение обозначенной тематики с итогов Второй мировой войны, когда лидеры СССР, США, Франции и Великобритании вступили в сложные переговоры 
относительно выработки Устава Организации Объединенных Наций [2] и учреждения международных трибуналов для суда над официальными высокопоставленными лицами Германии и Японии. Не имевший аналогов судебный орган наделялся правом судить высших должностных лиц суверенных государств вопреки их воле и желанию.

В непростых политических условиях сам фракт учреждения Нюрнбергского [3] и Токийского [4] военных трибуналов следует признать безоговорочной победой советской дипломатии. Однако и по настоящее время неразрешенными остаются следующие «монументальные» вопросы, касающиеся легитимности созданных трибуналов.

1. На примере Нюрнбергского трибунала - четыре государства учредили и провели суд над суверенным независимым участником международных отношений без получения от него согласия. Выдержан ли принцип международного права «равный над равным власти не имеет» (par in parem non habet imperium)?

2. Перечень преступлений, за совершение которых Нюрнбергский и Токийский трибуналы привлекали к ответственности, был утвержден уже после их совершения. Таким образом, международный договор имел обратную силу без согласия его «вынужденных» участников (в частности, Германии).

Указанные вопросы стали ключевыми аргументами линии защиты немецкого командования на Нюрнбергском процессе, что не было воспринято судьями как основание для прекращения судебного разбирательства или исключения лиц из числа подсудимых. Трибунал в Нюрнберге навсегда изменил международное право, продемонстрировав любому потенциальному нарушителю принцип неотвратимости наказания.

Спустя почти 50 лет возникла проблема недостаточности положений Устава ООН для быстрого и адекватного разрешения конфрликтной ситуации на территории Югославии. Положения гл. VII Устава ООН не содержат прямого указания на возможность учреждения Советом Безопасности $\mathrm{OOH}$ международных судебных инстанций (в том числе действующих на временной основе как вспомогательных органов [5] - Международного трибунала по бывшей Югославии (МТБЮ) и Международного трибунала по Руанде (МТР)) в целях прекращения нарушений международного гуманитарного права, восстановления мира и эфффективной защиты лиц, пострадавших от преступных деяний [6].

Однако авторы учреждающих трибуналы документов рассуждали логически верно: перечень возможных реакций Совета Безопасности на возникновение и развитие ситуаций, сопряженных с угрозой миру и безопасности, является открытым. Согласно ст. 39 Устава ООН Совет Безопасности решает, какие меры следует принять в соответствии со ст. 41 и 42 для поддержания или восстановления международного мира и безопасности. Статья 41 в свою очередь уполномочивает СБ ООН принимать меры, не связанные с применением вооруженной силы.

В результате МТБЮ был учрежден на основании гл. VII Устава Организации Объединенных Наций Резолюцией СБ ООН № 827 от 25.05.1993 г. [7]. Отсутствие в Уставе ООН ограничений на принятие Советом Безопасности конкретных мер послужило основанием для выработки нескольких основополагающих документов:

1) Резолюции № 808 от 22.02.1993 г.: «должен быть учрежден международный трибунал для судебного преследования лиц, ответственных за серьезные нарушения международного гуманитарного права, совершенные на территории бывшей Югославии с 1991 г.» (п. 1) [8];

2) Резолюции № 827 от 25.05.1993 г.: «международный трибунал создается в целях судебного преследования лиц, ответственных за серьезные нарушения международного гуманитарного права»;

3) Резолюции № 857 от 20.08.1993 г.: «утвержден список кандидатов на должности судей МТБЮ» [9].

В рамках первого оглашенного приговора председательствующая Г. Кирк Макдональд 07.05.1997 г. назвала МТБЮ первым истинно международным трибуналом, учрежденным Организацией Объединенных Наций (§ 1) [10]. В результате трибунал сам себя признал законным, умышленно «забыв» о необходимости выбора одной из двух следующих истинно возможных процедур учреждения.

1. Через международный договор на основании Венской конвенции 1969 г. [11]. Поясняя избранную тактику, Генеральный секретарь ООН в докладе отметил, что «даже при таком исходе невозможно гарантировать, что этот международный договор будет ратифицирован теми государствами, участие которых сделало бы его действительно эффрективным» (§ 20) [12].

2. Через решение на уровне Генеральной Ассамблеи $\mathrm{OOH}$, что не могло гарантировать минимальные сроки. Однако не стоит забывать, что быстро принятое и изначально неправомерное решение по истечении времени сможет стать исторически обоснованным, но никогда не станет правомерным. 
Незавершенность Резолюции СБ ООН в части невозможности указания на конкретную статью Устава ООН и неубедительность сторонников учреждения МТБЮ именно через Резолюцию СБ были использованы стороной защиты в рассмотренных трибуналом делах (по аналогии с Нюрнбергом). Так, адвокаты Д. Тадича утверждали, что для признания истинной законности трибунал должен быть учрежден или посредством договора, т. е. согласованного государствами акта, или через поправки в Уставе ООН (§ 27) [13]. Естественно, что ни один из озвученных защитой Д. Тадича вариантов не предполагал на тот момент возможности реализации, в том числе по причине фактического признания ошибочности запущенного «проекта» в случае инициирования полновесной процедуры.

Параллельно с МТБЮ начал функционировать Международный уголовный трибунал по Руанде (в текстах документов ООН он поименован как «Международный трибунал по Руанде») [14], который отражал реакцию Совета Безопасности ООН на разразившуюся в стране гражданскую войну и сопутствующие ей события.

Проблема неочевидной правовой аргументации полномочий Совета Безопасности ООН на учреждение международного трибунала по-прежнему актуальна для представителей отечественной правовой мысли. Так, С.А. Егоров указывает на сочетание юридического и филлософского аспектов вопроса:

1) неясным остается перечень государств, которые должны ратифицировать международный договор об учреждении МТБЮ;

2) позиция представителей Бразилии и Китая на момент создания МТБЮ сводилась к призванию уяснить исключительность исторической ситуации и не превращать спорное правомочие Совета Безопасности в прецедент.

Автор приводит фрагмент высказывания представителя КНР, назвавшего принятый Устав МТБЮ «правовым документом с атрибутами международного договора», который «идет вразрез с принципами суверенитета государств». По результатам анализа С.А. Егоров пришел к выводу, что вся доступная «прозрачность» в деятельности МТБЮ так и не смогла исключить восприятия трибунала как политического инструмента Запада [15].

Анализ особенностей учреждения международных уголовных трибуналов позволяет утверждать, что чрезвычайные обстоятельства не всегда могут быть заложены авторами в разрабатываемые и принимаемые международные документы. На примере привлечения к ответственности немецкого командования по итогам Второй мировой войны следует признать обоснованным игнорирование устоявшихся положений международного права в целях общей и частной превенции: впервые в истории международных отношений группа государств взяла на себя ответственность за сохранение мира и безопасности и провела четкую грань между дозволенным и недозволенным поведением любого участника международных отношений. Решительность в защите прав и свобод человека, сохранении мира и безопасности перестала быть теоретической моделью, воплотила в себе реальные представления об институте международной ответственности. Таким образом, государства отказались от неэффективного, но признаваемого международного права «довоенной» эпохи в пользу решительного, жесткого ответа союзников на злодеяния Второй мировой войны. Непреклонная позиция союзников дала мощный импульс разработке международного права нового поколения: цель защиты всех участников международных отношений вне зависимости от территории отныне имеет приоритет над любыми формальными неопределенностями и нежеланием их широкого толкования.

Результаты исследования избранной государствами - членами Совета Безопасности ОOH процедуры создания МТБЮ и МТР позволяют утверждать, что она вызывает достаточное количество вопросов как у теоретиков, так и у практиков: делается акцент на неочевидности прав у Совета Безопасности на учреждение вспомогательных судебных органов (при условии отсутствия у СБ судебных полномочий), закрепленных в Уставе ООН. Однако необходимо признать аргументированным заявление Генерального секретаря ООН в части объективной оценки временных и организационных затрат на внесение изменений в Устав $\mathrm{OOH}$ или ратификацию международного договора (в случае следования «очевидной» процедуре): такой шаг нивелировал бы значительный объем благ от учреждения трибуналов. Мы предполагаем, что следование полновесной процедуре и «смещение» момента начала полноценного функционирования МТБЮ и MTP в реальности завершились бы осознанием неактуальности созданных органов либо их формальным функционированием.

На основании изложенного нужно признать, что не существует международного документа, предусматривающего все возможные перспективные обстоятельства, в том числе исключительные (чрезвычайные). Международное право развивается вслед за изменением фрактических обстоятельств, стараясь «действовать на опережение»: и когда этого достичь не удается, основные 
субъекты имеют право на экстренные меры, не идущие вразрез с идеей сохранения международного мира и безопасности. Ключевыми пожеланиями при этом остаются адекватное восприятие уникальности сложившихся обстоятельств и отказ от «матричного» мышления в любой схожей (или удобной для одного из участников) ситуации.

\section{Ссылки:}

1. Каламкарян Р.А., Мигачев Ю.И. Международное право : учебник. М., 2006.

2. Устав Организации Объединенных Наций : принят в г. Сан-Франциско 26 июня 1945 г. // Сборник действующих договоров, соглашений и конвенций, заключенных СССР с иностранными государствами. М., 1956. Вып. XII. С. 14-47.

3. Устав Международного военного трибунала для суда и наказания главных военных преступников европейских стран оси : принят 8 авг. 1945 г. в г. Лондоне // Действующее международное право. М., 1997. Т. 3. С. 763-770.

4. Устав Международного военного трибунала для Дальнего Востока : принят 19 янв. 1946 г. в г. Токио // Сборник действующих договоров ... Вып. XII. С. 79-86.

5. Белый И.Ю. Международное уголовное правосудие и современный миропорядок // Международное право и международные организации. 2016. № 2. С. 238-256.

6. Костенко Н.И. Значение Организации Объединенных Наций в решении проблем господства права в конфликтных государствах // Там же. 2015. № 2. С. 178-191.

7. Резолюция Совета Безопасности ООН от 25 мая 1993 г. № 827 [Электронный ресурc]. URL: https://documents-ddsny.un.org/doc/UNDOC/GEN/N93/306/28/IMG/N9330628.pdf?OpenElement (дата обращения: 11.07.2017).

8. Доклад Генерального секретаря, представленный во исполнение п. 2 Резолюции Совета Безопасности ООН № 808 [Электронный ресурc]. URL: https://documents-dds-ny.un.org/doc/UNDOC/GEN/N93/098/21/IMG/N9309821.pdf?OpenElement (дата обращения: 11.07.2017).

9. Резолюция Совета Безопасности ООН от 20 авг. 1993 г. № 857 [Электронный ресурc]. URL: https://documents-ddsny.un.org/doc/UNDOC/GEN/N93/460/26/IMG/N9346026.pdf?OpenElement (дата обращения: 11.07.2017).

10. Prosecutor v. Dusko Tadic [Электронный ресурс] : Opinion and Judgment : Case no. IT-94-1-T. Ch. II : 7 May 1997. URL: http://www.icty.org/x/cases/tadic/tjug/en/tad-tsj70507JT2-e.pdf (дата обращения: 11.07.2017).

11. Венская конвенция о праве международных договоров : утв. 23 мая 1969 г. // Сборник действующих договоров ... М., 1988. Вып. XLII.

12. Доклад Генерального секретаря ...

13. Prosecutor v. Dusko Tadic ...

14. Устав Международного уголовного трибунала по Руанде [Электронный ресурс] : утв. Резолюцией Совета Безопасности ООН от 8 нояб. 1994 г. № 955. URL: http://www.un.org/ru/law/ictr/charter.shtml (дата обращения: 11.07.2017).

15. Егоров С.А. Международный уголовный трибунал по бывшей Югославии // Международное право и международные организации. 2014. № 4. С. 581-597.

\section{References:}

Bely, IYu 2016, 'International Criminal Justice and the Modern World Order', International Law and International Organizations, no. 2, pp. 238-256, https://doi.org/10.7256/2226-6305.2016.2.16851.

'Charter of the International Military Tribunal for the Far East, adopted on January 19, 1946 in Tokyo', Sbornik deystvuyushchikh dogovorov, soglasheniy i konventsiy, zaklyuchennykh SSSR s inostrannymi gosudarstvami, Issue XII, pp. 79-86, (in Russian).

'Charter of the International Military Tribunal for the Trial and Punishment of the Major War Criminals of the European Axis Countries, adopted on August 08, 1945 in London' 1997, Deystvuyushcheye mezhdunarodnoye pravo, Moscow, vol. 3, pp. 763770, (in Russian).

'Charter of the United Nations, adopted in San Francisco on June 26, 1945' 1956, Sbornik deystvuyushchikh dogovorov, soglasheniy i konventsiy, zaklyuchennykh SSSR s inostrannymi gosudarstvami, Issue XII, pp. 14-47, (in Russian).

Egorov, SA 2014, 'International Criminal Tribunal for the former Yugoslavia', Mezhdunarodnoye pravo i mezhdunarodnyye organizatsii, no. 4, pp. 581-597, (in Russian).

Kalamkaryan, RA \& Migachev, Yul 2006, International law, textbook, Moscow, (in Russian).

Kostenko, NI 2015, 'The Significance of the United Nations in Solving the Problems of the Rule of Law in Conflict States', International Law and International Organizations, no. 2, pp. 178-191, https://doi.org/10.7256/2226-6305.2015.2.14490.

Prosecutor v. Dusko Tadic: Opinion and Judgment: Case no. IT-94-1-T. Ch. II: 7 May 1997 2017, viewed 11 July 2017, <http://www.icty.org/x/cases/tadic/tjug/en/tad-tsj70507JT2-e.pdf>

Vienna Convention on the Law of Treaties, adopted on May 23, 1969 1988, Sbornik deystvuyushchikh dogovorov, soglasheniy i konventsiy, zaklyuchennykh SSSR s inostrannymi gosudarstvami, Issue XLII, (in Russian). 